\title{
Sediment sulfur dynamics related to biomass- density patterns in Zostera marina (eelgrass) beds
}

\author{
Marianne Holmer ${ }^{1, *}$, Søren Laurentius Nielsen ${ }^{2}$ \\ ${ }^{1}$ Institute of Biology, Odense University, Campusvej 55, DK-5230 Odense M, Denmark \\ ${ }^{2}$ Department of Life Sciences and Chemistry, Roskilde University, Postbox 260, DK-4000 Roskilde, Denmark
}

\begin{abstract}
Rates of sulfate reduction and the cycling of sulfur were measured in estuarine sediments vegetated with Zostera marina L. (eelgrass), and in adjacent bare sediment, in summer during the intensive period of the growth season. Sulfate reduction rates were determined along a shoot density gradient ( 210 to 1026 shoots $\mathrm{m}^{-2}$ ). There was a positive linear correlation between shoot density and depth-integrated sulfate reduction rates, and rates were 5 -fold higher at the dense station $159.1 \mathrm{mmol}$ $\left.\mathrm{m}^{-2} \mathrm{~d}^{-1}\right)$ than at the bare site $\left(12.2 \mathrm{mmol} \mathrm{m} \mathrm{m}^{-2} \mathrm{~d}^{-1}\right)$. The accumulation of particulate organic matter was low in the vegetated sediments, and there was no correlation between the organic content and microbial activity. The accumulation of dissolved organic carbon (DOC) was higher in the vegetated sediments, whereas pools of short chain fatty acids were low $(<5 \mu \mathrm{M})$ at all stations. There was a positive relationship between the depth-integrated DOC pool and sulfate reduction rates along the shoot density gradient, indicating a direct plant effect probably from a production of labile organic matter within the eelgrass bed. Sulfate reduction rates were primarily enhanced in the rooted zone. The cycling of sulfur compounds was rapid, as there was an accumulation of dissolved sulfides in the pore waters throughout the examined sediment layer $(0$ to $8 \mathrm{~cm})$ in the vegetated sediments. Burial of precipitated reduced sulfides increased with increasing shoot density, but the pools were low when related to the sulfate reduction rates, indicating a rapid reoxidation of sulfides at the location.
\end{abstract}

KEY WORDS: Eelgrass - Sediments Sulfate reduction DOC $\cdot$ Sulfides

\section{INTRODUCTION}

The role of seagrass meadows in the cycling of essential elements (i.e. nitrogen and phosphorus) is important owing to their ability to produce and accumulate organic matter including major nutrients (Kenworthy et al. 1982). Organic matter cycling is enhanced in vegetated sediments by: (1) entrapment and decomposition of allochthonous particulate organic material within the seagrass bed (Kemp et al. 1984); (2) microbial breakdown of dissolved organic compounds excreted from plant roots (Smith et al. 1988); (3) decomposition of senescent plant material (Barko et al. 1991).

As seagrasses are situated in sediments with high microbial activity, the highly reducing conditions could stress the macrophytes due to accumulation of reduced

•E-mail: holmer@biology.ou.dk metabolites. However, seagrasses have adapted to these reducing conditions by developing a system of internal lacunae for downward transport of $\mathrm{O}_{2}$ to support root respiration (Sand-Jensen et al. 1982, Smith et al. 1984, Caffrey \& Kemp 1991). Release of $\mathrm{O}_{2}$ from seagrass roots has the potential to alter both sediment microbiology and chemistry, and rhizosphere oxidation may result in elevated rates of nitrification and denitrification (Caffrey \& Kemp 1991). Furthermore, seagrasses may excrete labile photosynthetic compounds from the roots and rhizomes (Moriarty et al. 1985), resulting in increased concentrations of dissolved organic compounds in vegetated sediments (Koepfler et al. 1993). The activity of benthic bacteria in seagrass ecosystems is believed to be closely controlled by the production of overlying plants and the availability of nutrients in the sediments (Danovaro \& Fabiano 1995). López et al. (1995) found high bacterial activity in the sediments under Posidonia oceanica 
meadows, and attributed this to the plants' high supply of organic matter to the sediments, which were organically enriched relative to unvegetated sites.

Bacterial sulfate reduction is the predominant pathway of anaerobic mineralization of organic matter in coastal marine sediments, and accounts for more than half of the microbial decomposition in salt-marsh sediments, where rates of sulfate reduction are among the highest recorded (Howarth 1984). The pool of acidvolatile sulfides (dissolved sulfides and iron-monosulfides) is generally of minor importance in salt-marshes and mangrove sediments, whereas the burial of pyrite is high (Howarth 1984, Holmer et al. 1994). Oxidation of the sediments through root excretion has been suggested to aid the precipation of pyrite. The accumulation of sulfides decreases the oxidation of the sediments and may cause the sediment environment to deteriorate, e.g. affecting the growth conditions for eelgrass and reducing benthic faunal activity. Sulfur cycling has been described in e.g. salt marshes and mangroves (Howarth 1984, Holmer et al. 1994), but is less well known in other types of vegetated sediments (Blackburn et al. 1994, Isaksen \& Finster 1996).

In northern Europe and North America the dominant seagrass Zostera marina L. has declined significantly since the 1970s (Orth \& Moore 1983, Giesen et al. 1990). Increased nutrient enrichment leading to decreased light availability has been linked to this decline. In their investigation on the effect of sediment conditions on photosynthetic response, Goodman et al. (1995) found a decrease in maximum rate of photosynthesis and an increase in light intensity needed to obtain net photosynthesis with increasing sulfide concentration in the sediment. $Z$. marina often inhabits light-limited environments, and is adapted to tolerate anoxia and the presence of sulfides by using anaerobic fermentation for energy generation (Smith et al. 1988). In most plants, protein synthesis is disrupted upon transition from aerobiosis to anaerobiosis, and prolonged anoxia in combination with light-limitation may reduce the growth of plants. Elevated sulfide levels may, therefore, contribute to seagrass loss in stressed areas where the potential for light utilization is reduced, but $Z$. marina is uniquely tolerant of even severe anoxia (Kraemer \& Alberte 1995).

In the present study we measured pools of organic matter, reduced sulfides and rates of sulfate reduction along a gradient of increasing shoot density in a Zostera marina bed in Roskilde Fjord, Denmark, to evaluate the impact of seagrasses on sulfur cycling in sediments. Measurements of particulate and dissolved organic carbon pools within the eelgrass bed allowed assessment of the microbial substrates present for sulfate-reducing bacteria. Time course incubations were performed to determine sulfate reduction rates for evaluation of the core injection technique in vegetated sediments.

\section{MATERIALS AND METHODS}

Study area and sampling procedures. The study was conducted in a heterogenous Zostera marina stand at Ølsted Strand, Roskilde Fjord, Denmark, in June 1995. One unvegetated station ( $\operatorname{Stn} 1$ ) and 4 vegetated stations with increasing shoot density (Stns 2 to 5) were sampled at a water depth of $1.5 \mathrm{~m}$. The water temperature was $21^{\circ} \mathrm{C}$ and the salinity $13 \%$. Eelgrass density and biomass were determined by harvesting all plant material within 2 randomly chosen quadrats $\left(0.25 \mathrm{~m}^{2}\right.$ each) at each station. Plant material was washed on a $1 \mathrm{~mm}$ sieve, and transported back to the laboratory, where the shoot density was quantified. The plant material was then separated into shoot, root-rhizome and dead biomass. Dry weight (DW) was determined by drying to constant weight at $105^{\circ} \mathrm{C}$.

Sediment cores were collected immediately before harvesting the eelgrass. From each station 6 to 8 cores were taken (i.d. $=26 \mathrm{~mm}$ ) for determination of sulfate reduction rates and 3 cores (i.d. $=80 \mathrm{~mm}$ ) for pore water extraction and sediment characteristics. Cores were taken between the plants to avoid direct collection of shoots and root-rhizomes. Cores containing roots or rhizomes were discarded before analysis.

Pore water and sediment characteristics. Sediment cores (i.d. $=80 \mathrm{~mm}$ ) were brought back to the laboratory and kept at $5^{\circ} \mathrm{C}$ during a processing time of maximum $8 \mathrm{~h}$. The cores were sliced at $1 \mathrm{~cm}$ intervals down to $4 \mathrm{~cm}$ and then at $2 \mathrm{~cm}$ intervals down to $8 \mathrm{~cm}$ depth. Pore water was obtained by centrifugation $(10 \mathrm{~min}$, $1250 \times \mathrm{g}$ ) in double centrifuge tubes through precombusted $\mathrm{GF} / \mathrm{F}$ filters. Pore water was sampled for total $\mathrm{CO}_{2}\left(\mathrm{TCO}_{2}\right)(2 \mathrm{ml}$ sample preserved with $10 \mu \mathrm{l}$ of $125 \mathrm{mM} \mathrm{HgCl}_{2}$ which also precipitates sulfides), sulfate $\left(\mathrm{SO}_{4}{ }^{2-}\right)(400 \mu \mathrm{l}$ sample with $50 \mu \mathrm{l}$ of $0.1 \mathrm{M} \mathrm{HCl}$ added to liberate sulfides), dissolved sulfides (DS) (1 ml sample fixed with $10 \mu$ l of $1 \mathrm{M}$ zinc acetate), dissolved organic carbon (DOC) and short chain fatty acids (SCFA) $(1 \mathrm{ml}$ sample added $50 \mu \mathrm{l}$ of $0.1 \mathrm{M} \mathrm{HCl}$ to prevent precipitation). Samples for $\mathrm{TCO}_{2}$ were analysed within $4 \mathrm{~d}$, and $\mathrm{SO}_{4}{ }^{2-}$, DOC and SCFA were kept frozen until analysis within 2 mo. Sediment characteristics (density, water content, organic content) were determined concurrently with the pore water extraction.

Sulfate reduction rates. Sulfate reduction rates were measured by the core-injection technique (Jørgensen 1978), where $2 \mu \mathrm{l}$ of carrier-free ${ }^{35} \mathrm{~S}_{-\mathrm{SO}_{4}}{ }^{2-}(70 \mathrm{kBq})$ was injected at $1 \mathrm{~cm}$ intervals down to $10 \mathrm{~cm}$. Injections were done immediately after sampling, and cores were incubated for $1,2,4$, or 6 to 8 h conly 3 incubation times 
at Stns 1 to 3) at in situ temperature. The incubation was terminated by slicing the sediment at $1 \mathrm{~cm}$ intervals down to $4 \mathrm{~cm}$ and $2 \mathrm{~cm}$ intervals down to $8 \mathrm{~cm}$ depth directly into $1 \mathrm{M}$ zinc acetate. The sediment was kept frozen until analysis. Background contamination of ${ }^{35} \mathrm{~S}$ was determined by slicing and fixing one core from Stn 5 before the addition of radioisotope (Fossing pers. comm.).

The sediment was distilled according to the 2-step procedure of Fossing \& Jorgensen (1989). Briefly, 3 to $5 \mathrm{~g}$ of centrifuged sediment ( 5 min, $2500 \times g$ ) was transferred to a reaction flask and $10 \mathrm{ml}$ of $50 \%$ ethanol was added. After degassing with $\mathrm{N}_{2}$ for $10 \mathrm{~min}, 8 \mathrm{ml} 12 \mathrm{M} \mathrm{HCl}$ was added before the slurry was distilled at room temperature for 30 min to obtain the acid-volatile fraction (AVS). The reducible sulfur compounds were released as $\mathrm{H}_{2} \mathrm{~S}$ and trapped as $\mathrm{ZnS}$ in $10 \mathrm{ml}$ of $250 \mathrm{mM}$ zinc acetate. A new trap was inserted, $16 \mathrm{ml}$ of $1 \mathrm{M} \mathrm{Cr}^{2+}$ in $0.5 \mathrm{M} \mathrm{HCl}$ was added to the reaction flask, and the mixture was distilled by boiling for 30 min to obtain the chromium reducible sulfur (CRS). Subsamples from supernatants and suspended ZnS from the traps were mixed with Ultima Gold scintillation cocktail, and radioactivity was counted on a Packard TriCarb 2000 scintillation counter. The total sulfate reduction rate $\left(\mathrm{SRR}_{\text {tot }}\right)$ was calculated by addition of sulfate reduction rates based on the AVS $\left(\mathrm{SRR}_{\mathrm{AVS}}\right)$ and the CRS (SRR $\mathrm{CRS}_{\mathrm{S}}$ ) fractions. The pools of reduced inorganic sulfur ( $P_{\mathrm{AvS}}$ and $\mathrm{P}_{\mathrm{CRS}}$ ) were determined as total amount of sulfide trapped by the spectrophotometric method of Cline (1969).

Analysis. $\mathrm{TCO}_{2}$ was measured by the flow injection technique of Hall \& Aller (1992). $\mathrm{SO}_{4}{ }^{2-}$ was measured by ion-chromatography with a Dionex auto-suppressed anion-system (IonPac AS4A-SC column and ASRS suppressor). Dissolved sulfides were determined by the method of Cline (1969). DOC was measured with a Shimadzu TOC-5000 total organic carbon analyzer on acidified samples and SCFA with a Dionex chemical-suppressed ion-exclusion principle using a IonPac ICE-AS6 column (Dionex Corp.) and $0.4 \mathrm{mM}$ $\mathrm{HCl}$ as eluent followed by an Anion-MicroMembrane Suppressor (AMMS-ICE, Dionex) with $5.00 \mathrm{mM}$ tetrabutylammonium hydroxide as regenerant (Bøtte \& Jørgensen 1992. Holmer \& Kristensen 1994).

Sediment density was obtained by weight of known sediment volume and water content was measured as weight loss after drying overnight at $105^{\circ} \mathrm{C}$ and used in calculations of sulfate reduction rates. Particulate organic carbon (POC) and nitrogen (PON) were determined (1 core from each station $)$ on pre-dried $\left(105^{\circ} \mathrm{C}\right)$ sediment after subtraction of the inor- ganic carbon and nitrogen measured on ignited $\left(520^{\circ} \mathrm{C}\right)$ sediment according to Kristensen \& Andersen (1987) using a Carlo Erba 1100EA elemental analyzer.

\section{RESULTS}

\section{Eelgrass and sediment data}

Eelgrass density increased with a factor of 5 from Stn 2 (210 shoots $\mathrm{m}^{-2}$ ) to Stn 5 (1026 shoots $\mathrm{m}^{-2}$ ) (Table 1). A positive, significant relationship between shoot density and both shoot biomass $\left(y=0.02 x^{1.32}\right.$, $\left.\mathrm{R}^{2}=0.801, \mathrm{p}=0.003\right)$ and root-rhizome biomass $(y=$ $0.07 x^{1.16}, R^{2}=0.814, p=0.002$ ) could be described with a power function: $y=A x^{B}$. The exponent $(B)$ was $>1$ indicating a relative increase in individual plant weight from Stn 2 towards Stn 5. The root-rhizome fraction accounted for 54 to $63 \%$ of the total living biomass with the highest fraction at the lowest density. There was no significant correlation between shoot density and dead biomass $\left(R^{2}=0.077, p=0.506\right)$. Dead biomass varied at $\operatorname{Stn} 2$ where 1 of the 2 samples showed a very high value (114.0 g dry wt $\left.\mathrm{m}^{-2}\right)$; otherwise the relative fraction of dead biomass (dead:total) was negatively related to shoot density, reaching $14.2 \%$ of the total biomass at Stn 2 (high value at Stn 2 omitted)

The POC and PON content in the sediment was low at all 5 stations $(\mathrm{POC}<0.206 \%$ dry wt, $\mathrm{PON}<0.010 \%$ dry wt) with an erratic depth pattern (data not shown). The depth-integrated POC content (0 to $8 \mathrm{~cm})$ increased from the unvegetated site $\left(10.9 \mathrm{~mol} \mathrm{C} \mathrm{m}^{-2}\right)$ along the density gradient to a maximum at Stn 3 (19.6 mol $\mathrm{C} \mathrm{m}^{-2}$ ) and decreased again at Stns 4 and 5 (12.6 to $15.1 \mathrm{~mol} \mathrm{C} \mathrm{m}^{-2}$ ). There was no significant relationship between $\mathrm{POC}$ and dead biomass (leastsquares regression: $\mathrm{R}^{2}=0.056, \mathrm{p}=0.574$ ). PON content was generally close to the detection limit of the analysis, and the presented data are probably maximum values.
Table 1 . Eelgrass data at the 4 vegetated stations. Shoot density and shoot, rhizome+root and dead biomass are given as mean ( \pm range) of 2 collections. Rhizome-root biomass is given as percentage of the total living biomass (RR:tot = rhizome+root/shoot+rhizome+root). The dead biomass is calculated similarly (Dead:tot $=$ dead $/$ shoot + rhizome + root $)$

\begin{tabular}{|ccccccc|}
\hline Stn & $\begin{array}{c}\text { Shoot } \\
\text { density } \\
\left(\text { shoot } \mathrm{m}^{-2}\right)\end{array}$ & $\begin{array}{c}\text { Shoot } \\
\text { biomass } \\
\left(\mathrm{g} \mathrm{DW} \mathrm{m} \mathrm{m}^{-2}\right)\end{array}$ & $\begin{array}{c}\text { Rhizome+ } \\
\text { root biomass } \\
\left(\mathrm{g} \mathrm{DW} \mathrm{m}^{-2}\right)\end{array}$ & $\begin{array}{c}\text { Dead } \\
\text { biomass } \\
\left(\mathrm{g} \mathrm{DW} \mathrm{m}^{-2}\right)\end{array}$ & RR tot & Dead tot \\
\hline 2 & $210 \pm 34$ & $19.0 \pm 2.3$ & $29.6 \pm 0.4$ & 4.2 & 60.8 & 14.2 \\
3 & $336 \pm 156$ & $29.6 \pm 1.1$ & $49.4 \pm 10.5$ & $3.7 \pm 3.0$ & 62.5 & 4.5 \\
4 & $696 \pm 8$ & $145.1 \pm 55.5$ & $169.2 \pm 60.7$ & $1.8 \pm 0.4$ & 53.8 & 0.6 \\
5 & $1026 \pm 94$ & $194.8 \pm 3.7$ & $238.0 \pm 123.6$ & $5.2 \pm 0.5$ & 55.0 & 1.2 \\
\hline
\end{tabular}




\section{Dissolved carbon pools}

The DOC attained concentrations between 0.9 and $4.5 \mathrm{mM}$ with highest values in the deep layers at the vegetated sites (Fig. 1). The depth profiles were separated into a rooted layer $(0$ to $4 \mathrm{~cm}$ ) and a non-rooted zone $(4$ to $8 \mathrm{~cm})$. The effect of increasing shoot density in each layer was tested with a regression analysis. There was a significant increase with shoot density in both the rooted layer and below, which was linearly correlated with shoot density (Fig. 2). The depth-integrated DOC pool (0 to $8 \mathrm{~cm}$ ) (IDOC) showed a significant positive relationship with shoot density (leastsquares regression: $y=0.024 x+6.717, R^{2}=0.857, p<$ $0.001)$. Despite the elevated pools of DOC in the vegetated sediments, the concentration of SCFA was below detection limit $(<5 \mu \mathrm{M})$ at all sites (data not shown). The concentration of $\mathrm{TCO}_{2}$ was almost constant with

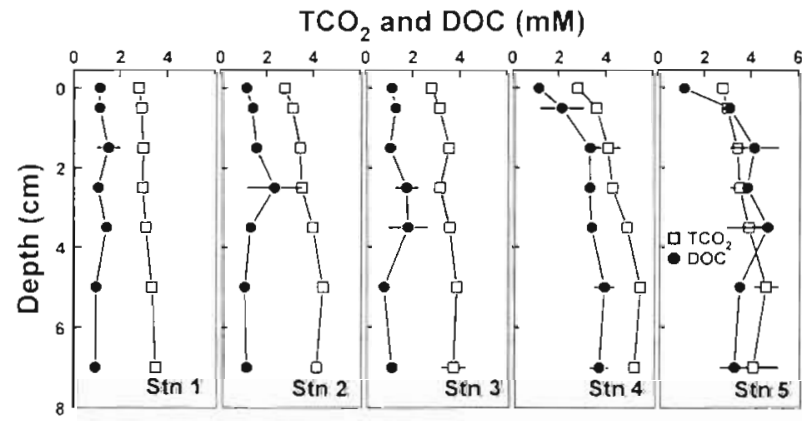

Fig. 1. Depth profiles of $\mathrm{TCO}_{2}$ and dissolved organic carbon (DOC) at the 5 examined stations. Each point is the average of 2 sediment cores ( \pm range)

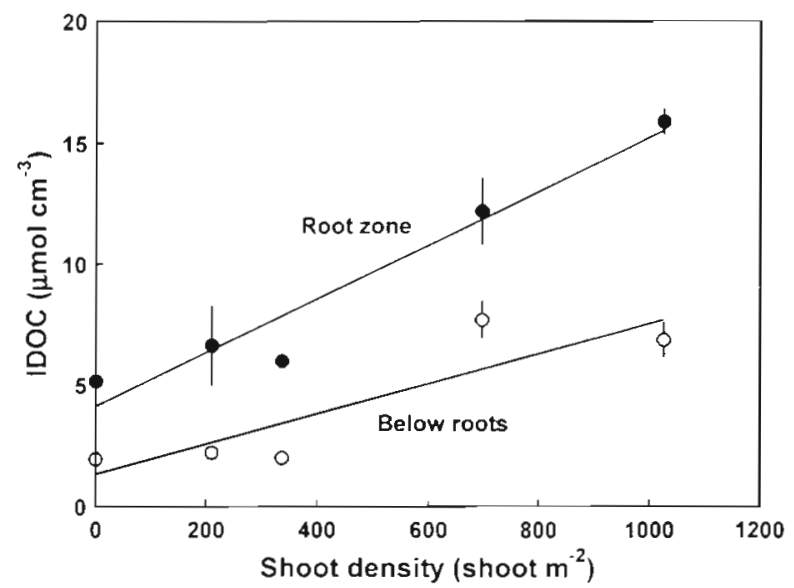

Fig. 2. Depth-integrated DOC pools in the root zone (-) and below roots (0) plotted against shoot density. Each point is the average of 2 cores ( \pm range). The best fit with linear least squares analysis is given (root zone: $y=0.011 x+4.104, \mathrm{R}^{2}=$ $0.893, p<0.001$; below roots: $y=0.006 x+1.306, R^{2}=0.749$, $p=0.001)$ depth at the unvegetated site (2.8 to $3.5 \mathrm{mM}$ ) (Fig. 1), whereas it increased with depth at the vegetated sites. There was, however, no significant relation between $\mathrm{TCO}_{2}$ concentration and shoot density in the 2 layers (least-squares regression: root zone: $R^{2}=0.242, p=$ 0.149 ; below roots $\mathrm{R}^{2}=0.306, \mathrm{p}=0.097$ )

\section{Sulfate reduction rates (SRR)}

Regression analysis of the depth-integrated sulfate reduction rate ( $\mathrm{ISRR}_{\mathrm{tol}}$ ) showed that $\mathrm{ISRR}_{\mathrm{tot}}$ was independent of incubation time at all stations (Table 2). By relating $\mathrm{ISRR}_{\mathrm{to}}$ with shoot density, a positive linear relation was evident (least-squares regression: $\mathrm{R}^{2}=$ $0.902, p=0.013$ ) (Fig. 3), showing a 5-fold increase from Stn 1 , the unvegetated site $\left(12.2 \mathrm{mmol} \mathrm{m}^{-2} \mathrm{~d}^{-1}\right)$, to Stn 5 (59.1 mmol m-2 $\mathrm{d}^{-1}$ ) with highest shoot density. There was no linear correlation between $\mathrm{ISRR}_{\text {tot }}$ and dead biomass $\left(\mathrm{R}^{2}=0.127, \mathrm{p}=0.073\right)$

The depth profile of $\mathrm{SRR}_{\text {tot }}$ generally showed decreasing activity with sediment depth at all stations (Fig. 4) and SRR CRS was the larger component at all

Table 2. Results of least-squares regression analysis of depthintegrated sulfate reduction rates versus incubation time. $n$ : number of cores; $R^{2}$ and $p$ values of the regression are given

\begin{tabular}{|ccrc|}
\hline $\operatorname{Stn}$ & $\mathrm{n}$ & $\mathrm{R}^{2}$ & $\mathrm{p}$ \\
\hline 1 & 6 & $<0.001$ & 0.989 \\
2 & 6 & 0.449 & 0.145 \\
3 & 6 & 0.218 & 0.350 \\
4 & 8 & 0.343 & 0.127 \\
5 & 8 & 0.218 & 0.243 \\
\hline
\end{tabular}

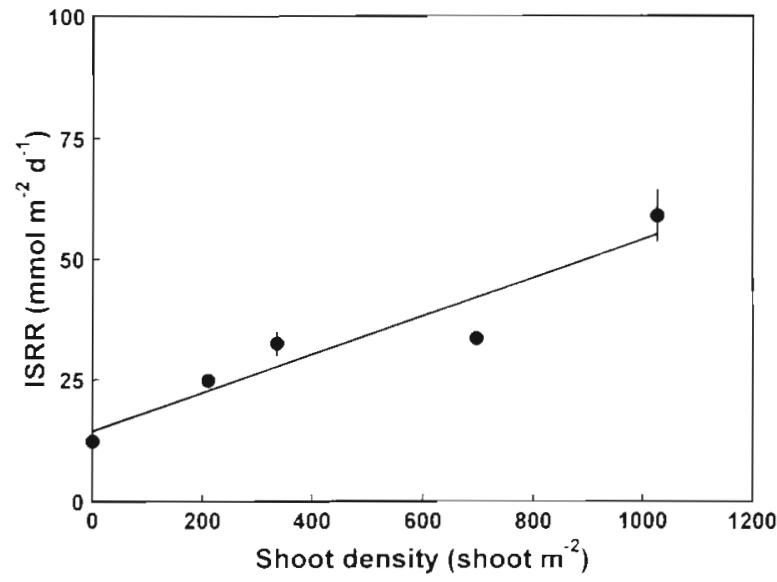

Fig. 3. Depth-integrated sulfate reduction rates (ISRR) plotted against shoot density. Each point is the average of 6 to 8 sedlment cores $( \pm \mathrm{SE})$. The best fit with linear least squares analysis is given: $y=0.036 x+15.055, R^{2}=0.902, p=0.013$ 

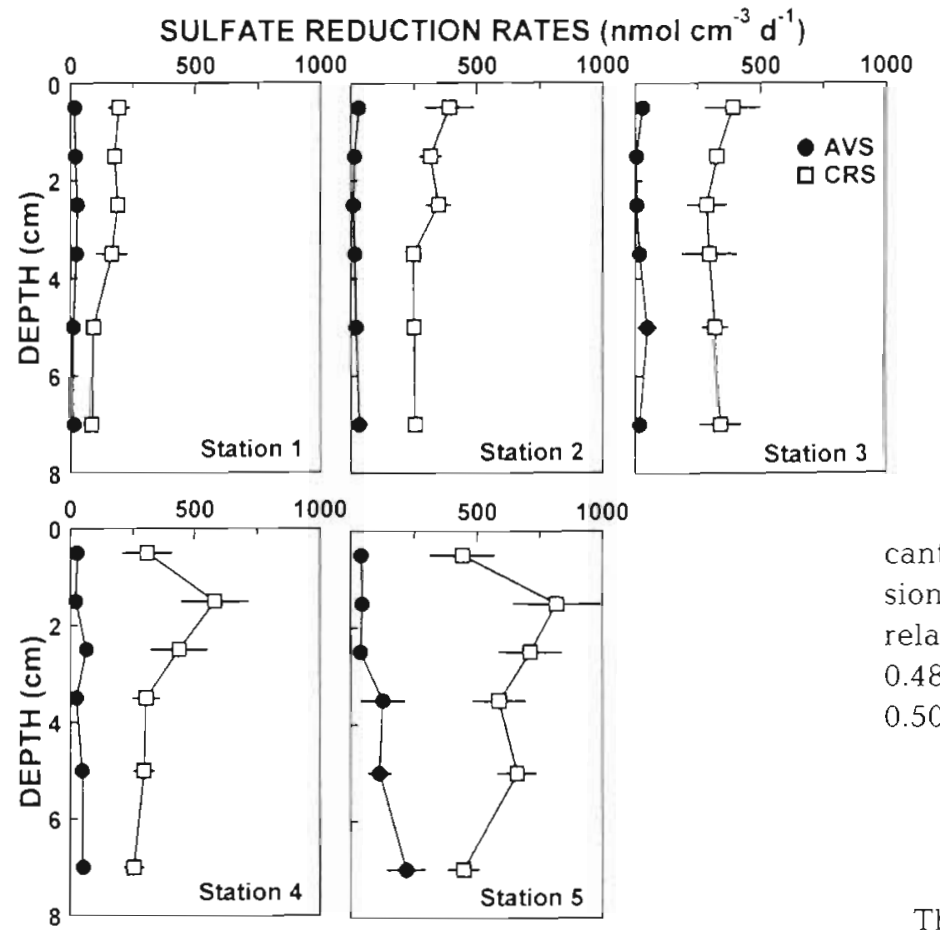

Fig. 4. Depth profiles of sulfate reduction rates at the 5 sta-

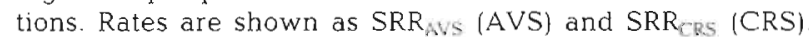

Each point is the average of 6 to 8 sediment cores ( $\pm \mathrm{SE}$ )

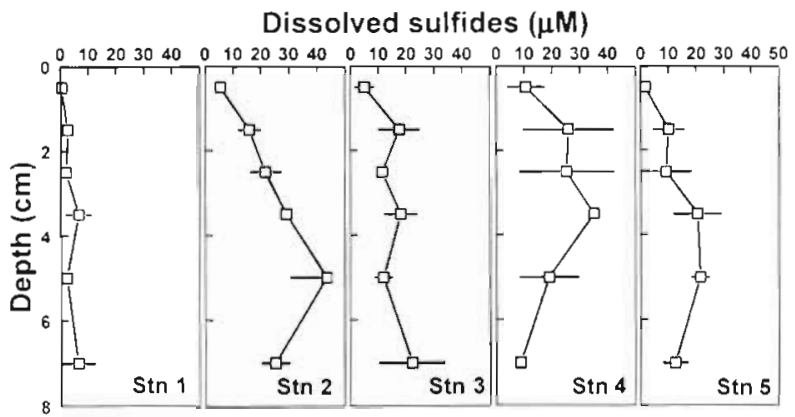

Fig. 5. Depth profiles of dissolved sulfides at the 5 examined stations. Each point is the average of 2 sediment cores ( \pm range)

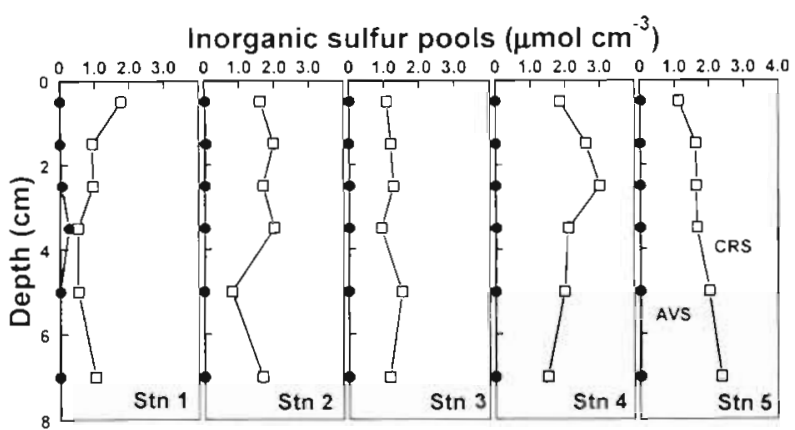

Fig. 6. Depth profiles of reduced sulfur pools at the 5 examined stations. Pools are separated into acid-volatile (AVS) and chromium reducible sulfur (CRS) pools. Each point is the average of 3 sediment cores depths $\left(\mathrm{SRR}_{\mathrm{CRS}}>69 \%\right.$ of $\left.\mathrm{SRR}_{\text {tot }}\right) . \mathrm{SRR}_{\mathrm{AVS}}$ was low in the surface layer ( 1 to $2 \%$ of $S_{R R}$ t) and increased with depth ( 5 to $31 \%$ of $S_{R R}$ ). At the unvegetated site $S R R_{\text {tot }}$ decreased from the surface (211 nmol cm-3 $\mathrm{d}^{-1}$ ) down to $6-8 \mathrm{~cm}$ $\left(95 \mathrm{nmol} \mathrm{cm}^{-3} \mathrm{~d}^{-1}\right)$. At the 2 stations with the highest shoot density $\mathrm{SRR}_{\mathrm{tot}}$ attained a subsurface maximum at 1 to $2 \mathrm{~cm}$ depth $(613$ and $862 \mathrm{nmol} \mathrm{cm}^{-3} \mathrm{~d}^{-1}$ at Stns 4 and 5, respectively). At Stns 2 and $3 \mathrm{SRR}_{\mathrm{tol}}$ had a pattern similar to the unvegetated site, although the overall rates were higher (up to $479 \mathrm{nmol} \mathrm{cm}^{-3} \mathrm{~d}^{-1}$ ). $\mathrm{SRR}_{\text {tot }}$ increased with shoot density with the most significant increase in the surface layers (1 to $4 \mathrm{~cm}$ ). Regression analysis showed a significant positive linear relationship with shoot density in both zones (root: $y=$ $0.481 x+207.9, R^{2}=0.939, p=0.006$; below roots: $y=$ $\left.0.504 x+136.5, R^{2}=0.819, p=0.035\right\}$.

\section{Sulfur pools}

The inorganic sulfur pools were measured as dissolved sulfides (DS) (Fig. 5) and as particulate pools separated into acid-volatile ( $P_{\text {Avs }}$ ) and chromium reducible sulfur ( $P_{C R S}$ ) (Fig. 6). At the unvegetated site the concentration of dissolved sulfides was below detection limit in the surface layer and increased with depth (to $6.5 \mu \mathrm{M}$ ). At the vegetated sites DS were present $(1.1$ to $10.5 \mu \mathrm{M})$ in the surface layer $(0$ to $1 \mathrm{~cm})$ but showed highest concentrations at 2 to $6 \mathrm{~cm}$ depth (up to $43 \mu \mathrm{M}$ ). This corresponds to the sediment depth where maximal SRR was found. There was a significant difference among the stations (2-way ANOVA: $\left.F_{4,20}=3.222, p=0.045\right)$, whereas there was no difference between the rooted layer and below $\left(F_{1,20}=2.957\right.$. $\mathrm{p}=0.108) . \mathrm{P}_{\text {AVS }}$ was low at all stations $\left(<70 \mathrm{nmol} \mathrm{cm}^{-3}\right)$. and $P_{C R S}$ accounted for $>93 \%$ of the total sulfide pool ( 0.6 to $3.2 \mu \mathrm{mol} \mathrm{cm}{ }^{-3}$ ). $P_{C R S}$ was generally higher at the vegetated stations, except for the 0 to $1 \mathrm{~cm}$ layer. There was no significant trend with shoot density in the rooted layer (least-squares regression: root zone: $\mathrm{R}^{2}=$ $0.194, \mathrm{p}=0.458$ ), whereas there was a positive linear relationship below the roots $\left(y=0.003 x+1.738, \mathrm{R}^{2}=\right.$ $0.981, p=0.001)$. The depth-integrated $\mathrm{P}_{\mathrm{CRS}}$ also showed a positive trend with increasing shoot density (Fig. 7).

\section{DISCUSSION}

\section{Eelgrass location}

The 4 vegetated stations examined here were situated at a location with many small $\left(<200 \mathrm{~m}^{2}\right)$ Zostera 


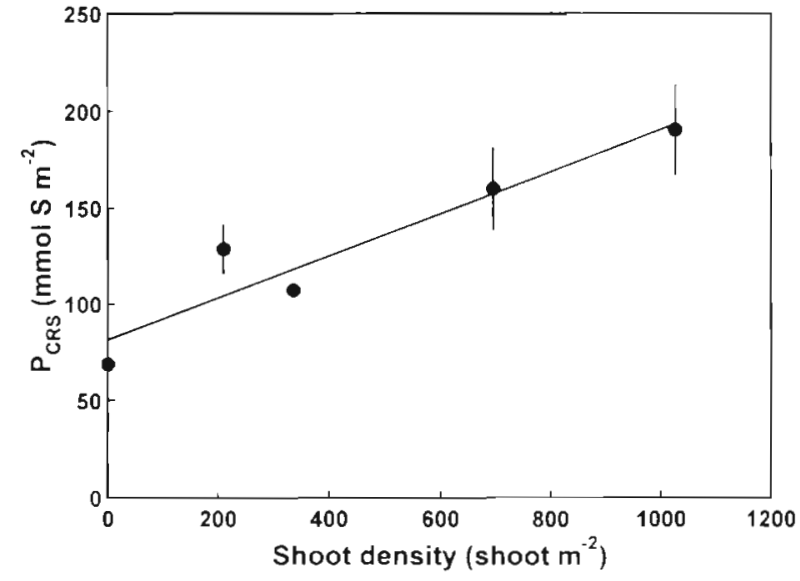

Fig. 7 Depth-integrated chromium reducible sulfur pools plotted against shoot density. Each point is the average of 3 sediment cores $( \pm \mathrm{SE})$. The best fit with linear least squares analysis is given: $y=0.109 x+81.343, R^{2}=0.900, p<0.001$

marina patches, and due to the shallow water depth, the eelgrass patches are exposed to high physical disturbance and resuspension. The examined eelgrass population is important in stabilizing the sediments, but may also experience a high degree of seasonal and annual variability. The shoot density and the living biomass of shoots and rhizomes fall in the range of those found in other eelgrass patches (Sand-Jensen 1975, Jacobs 1979, Wium-Andersen \& Borum 1984, Olesen \& Sand-Jensen 1994). The observed shoot:root (including rhizome) ratio which is lower than 1 is in accordance with Olesen \& Sand-Jensen (1994), and the high percentage of below-ground allocation indicated perennial eelgrass populations (Sand-Jensen 1975, Robertson \& Mann 1984).

\section{Sulfate reduction within the eelgrass bed}

The was no effect of increasing incubation time in the determination of depth-integrated sulfate reduction rates, indicating that the sulfate reduction activity was constant during the incubation and that reoxidation of reduced label was insignificant. Isaksen \& Finster (1996) suggested shorter incubation times $(<0.5 \mathrm{~h})$ to avoid reoxidation in the sediments with oxidized root zones. In this study dissolved sulfides were present throughout the examined depth interval, and the sediments were reduced, limiting reoxidation (Moeslund et al. 1994).

Sulfate reduction rates were stimulated by the presence of eelgrass, and there was a strong correlation between the density of living plants and the depthintegrated sulfate reduction rate $\left(\mathrm{ISRR}_{\mathrm{tot}}\right)$ (Fig. 3), whereas there was no correlation with dead biomass.
The obtained rates of sulfate reduction were high in the vegetated sediments compared to most coastal sediments (Thode-Andersen \& Jørgensen 1989, Moeslund et al. 1994), but similar high sulfate reduction rates have been measured in Spartina sp. marsh sediments (Hines et al. 1994) and in sediments vegetated with Zostera noltii (Isaksen \& Finster 1996) and Halodule beaudetti (Blackburn et al. 1994). Stimulation of microbial activity measured as aerobic respiration, nitrification and denitrification has also been observed in eelgrass beds (Caffrey \& Kemp 1990), indicating that the entire sediment metabolism is enhanced, and not only sulfate reduction as measured here. Smith et al. (1984) found a release of $\mathrm{O}_{2}$ from the roots, and in accordance with the $\mathrm{O}_{2}$ release Caffrey \& Kemp (1991) found that aerobic respiration and nitrification was enhanced. Denitrification, in turn, is stimulated by the release of nitrate from nitrification.

Sulfate reduction in coastal sediments is primarily controlled by temperature and input of organic substrates (Moeslund et al. 1994). Temperature was similar at all 5 sites during measurements, whereas sedimentation of organic debris probably is density dependent, as the denser eelgrass stands hamper water movement and thus increase the sedimentation rate to a higher degree than scattered stands. Seagrass beds have been shown to act as sinks of allochthonous organic matter in the form of phytoplanktonic detritus, land run-off and resuspended matter (Velimirov 1987, Pérez-Lloréns \& Niell 1993, Dauby et al. 1995). The sediment organic content was low at all sites, and there was no correlation between organic content and shoot density, indicating that either the deposition of organic matter was low or that the turnover was high. External sources are possibly more important during spring bloom sedimentation and winter organic inputs (Danovaro \& Fabiano 1995). Autochthonous sources of organic matter may relate directly to the shoot density. Blum \& Mills (1991) found that fresh eelgrass detritus loses $20 \%$ of its original dry weight within $1 \mathrm{~d}$, and an additional $20 \%$ within the following $20 \mathrm{~d}$ due to leaching. Leached material is often labile and may be rapidly utilized by bacteria. The poor correlation between dead biomass and ISRR, on the other hand, is probably due to the fact that the labile pool only accounts for a low and variable fraction of the total organic pool. Lopéz et al. (1995) suggested that the enhanced input of organic matter from the seagrasses explains a positive correlation between the production of Posidonia oceanica and bacterial activity, and Blackburn et al. (1994) propose that excretion of organic matter directly from the plants supports a high sulfate reduction rate in rooted depths. Isaksen \& Finster (1996), however, found no difference in sulfate reduction 
rates during illumination and darkness, and they suggest that organic molecules that fuel sulfate reducers are produced by microbial hydrolysis of macromolecules within the sediment. Release of organic matter from the rhizome and roots of Zostera marina has been found during photosynthesis and growth (Smith et al. 1988), and in this study pore water DOC pools increased with increasing plant density. Sulfate reduction rates were higher in the rooted layers compared to the layers below, and showed a positive relation with the shoot density, with the steepest increase in rates in the rooted layers. The depthintegrated SRR and the depth-integrated DOC pool show a weak positive correlation $(y=1.171 \mathrm{x}+$ 11.224, $R^{2}=0.602, p=0.008$ ). Koepfler et al. (1993) also found higher DOC concentrations in sediments vegetated with Halodule wrightii compared to a bare site, and they found a positive correlation between sediment oxygen uptake and pore water DOC concentration, suggesting that the total sediment metabolism is related to the DOC concentration. Kristensen \& Hansen (1995) found high accumulation of DOC and stimulated microbial activity during decomposition of macrophyte detritus (Ruppia maritima) within the sediment. SCFA may be important components of the DOC pool, as alcohols are excreted from the roots of $Z$. marina (Smith et al. 1988). Alcohols may rapidly be degraded to SCFA, but concentrations were low in the vegetated sites, indicating a low production or rapid turnover of these substrates. SCFA are considered important microbial substrates to sulfate-reducing bacteria (Parkes et al. 1989). Hines et al. (1994) found high concentrations of acetate in salt-marsh sediments with stands of Spartina sp. They measured acetate oxidation rates lower than the sulfate reduction rates, and suggested that sulfate-reducing bacteria may utilize other compounds than acetate in vegetated sediments.

\section{Sulfur pools in vegetated sediments}

The high sulfate reduction activity in the vegetated sediments resulted in enhanced pools of reduced sulfur compared to the unvegetated site. The increase was most noticeable for dissolved sulfides. Isaksen \& Finster (1996), on the other hand, did not detect dissolved sulfides despite high rates of sulfate reduction in sediments with Zostera noltii, and Blackburn et al. (1994) found low pools of reduced sulfides (dissolved and precipitated) in sediments vegetated by Halodule beaudetti roots. They suggested that sulfides are rapidly reoxidized by the excretion of $\mathrm{O}_{2}$ from the roots. Dissolved sulfides are usually not found close to the surface in low-organic sandy coastal sediments, where the reoxidation with e.g. oxidized Fe and $\mathrm{Mn}$ is rapid (Moeslund et al. 1994, Thamdrup et al. 1994). A high reoxidation was also expected in eelgrass sediments due to excretion of oxidized compounds through the roots (Smith et al. 1984, Caffrey \& Kemp 1990), but. the high sulfate reduction activity may have exceeded the reoxidation capacity. The dissolved sulfides can affect the growth of the plants, as Goodman et al. (1995) found reduced rates of photosynthesis at similar sulfide concentrations.

The pools of precipitated reduced sulfides ( $\mathrm{P}_{\text {AVS }}$ and $P_{C R S}$ ) showed no significant increase with depth, indicating that the burial of reduced sulfides was low. $P_{\text {Avs }}$ was very low at all sites, implying that the formation of pyrite (CRS) was rapid in accordance with the SRR $\mathrm{CRS}_{\mathrm{C}}$ measured at the site, and suggesting that the route for burial of sulfides is similar to salt marshes and mangrove sediments with pyrite as the main sulfide precipitant (Howarth 1984, Holmer et al. 1994). The pools of pyrite were low when compared to salt marshes and mangrove sediments, probably due to reoxidation of the buried sulfides during autumn and winter storms where the sediments are physically disturbed. The depth-integrated pools of $\mathrm{P}_{\mathrm{CRS}}$ showed a positive correlation with shoot density, indicating that the higher sulfate reduction activity resulted in increased burial of reduced sulfides despite the high degree of reoxidation. The accumulation of sulfides cause a reduced sediment environment, which may limit the floral and faunal activity, and visual inspections at the location showed almost no faunal activity inside the eelgrass patches. As no historical records are available for the examined eelgrass bed, the smallness of the difference in sulfide burial between the bare and the vegetated sediments could also be due to recent eelgrass colonization.

\section{CONCLUSIONS}

Our results suggest a strong positive relationship between plant abundance and sediment bacterial activity in eelgrass beds. The relationship may involve a direct plant effect resulting from the production of autochthonous labile organic matter within the eelgrass bed as indicated by an accumulation of dissolved organic carbon in the pore waters. The high sulfate reduction results in a rapid sulfur cycling with dissolved sulfides present in the pore waters and an elevated pool of precipitated reduced sulfides within the eelgrass bed. We conclude that the sulfur and organic matter cycling is directly related to the density of the seagrass population in Roskilde Fjord, probably because of enhanced inputs of organic matter by the seagrasses. 
Acknowledgements. We thank Susanne Boeriths, Gitte Wikstrom and Pernille Greve for excellent technical support during field work and laboratory analysis. Thanks are also due to Erik Kristensen and 3 anonymous reviewers for comments on the manuscript.

\section{LITERATURE CITED}

Barko JW, Gunnison D, Carpenter SR (1991) Sediment interactions with submersed macrophyte growth and community dynamics. Aquat Bot 41:41-65

Blackburn TH, Nedwell, DB, Wiebe WJ (1994) Active mineral cycling in a Jamaican seagrass sediment. Mar Ecol Prog Ser 110:233-239

Blum LK, Mills AL (1991) Microbial growth and activity during the initial stages of seagrass decomposition. Mar Ecol Prog Ser 70:73-82

Bøtte HF, Jørgensen L (1992) Evaluation of low-conductance eluents for suppressed ion-exclusion chromatography. J Chromatogr 602:27-31

Caffrey JM, Kemp VM (1990) Nitrogen cycling in sediments with estuarine populations of Potamogeton perfohatus and Zostera marina. Mar Ecol Prog Ser 66:147-160

Caffrey JM, Kemp WM (1991) Seasonal and spatial patterns of oxygen production, respiration and root-rhizome release in Potamogeton perfoliatus L. and Zostera marina L. Aquat Bot 40:109-128

Cline JD (1969) Spectrophotometric determination of hydrogen sulfide in natural waters. Limnol Oceanogr 14: $454-458$

Danovaro R, Fabiano M (1995) Seasonal and inter-annual variation of bacteria in a seagrass bed of the Mediterranean Sea: relationship with labile organic carbon compounds and other environmental factors. Mar Ecol Prog Ser 9:17-26

Dauby $P$, Bale A, Bloomer N, Canon C, Ling RD, Norro A, Robertson JE, Simon A, Théate JM, Watson AJ, Frankignoulle $M$ (1.995) Particle fluxes over a Mediterranean seagrass bed: a one year case study. Mar Ecol Prog Ser 126: $233-246$

Fossing $H$, Jorgensen BB (1989) Measurement of bacterial sulfate reduction in sediments: evaluation of a single-step chromium reduction method. Biogeochem 8:205-222

Giesen WBJ, van Katwijk MM, den Hartog D (1990) Eelgrass conditions and turbidity in the Dutch Wadden Sea. Aquat Bot 37:71-85

Goodman JL, Moore KA, Dennison WC (1995) Photosynthetic responses of eelgrass (Zostera marina L.) to light and sediment sulfide in a shallow barrier island lagoon. Aquat Bot $50: 37-47$

Hall POJ, Aller RC (1992) Rapid, small-volume, flow injection analysis for $\Sigma \mathrm{CO}_{2}$ and $\mathrm{NH}_{4}{ }^{+}$in marine and freshwaters. Limnol Oceanogr 37:1113-1118

Hines ME, Banta GT, Giblin AE, Hobble JE, Tugel JB (1994) Acetate concentrations and oxidation in salt-marsh sediments. Limnol Oceanogr 39(1):140-147

Holmer M. Kristensen E (1994) Organic matter mineralization in an organic-rich sediment: experimental stimulation of sulfate reduction by fish food pellets. FEMS Microbiol Ecol $14: 33-44$

Holmer M, Kristensen E. Banta G, Hansen K, Jensen MH, Bussawarit N (1994) Biogeochemical cycling of sulfur and iron in sediments of a south-east Asian mangrove. Phuket Island, Thailand. Biogeochem 26:145-161

Howarth RW (1984) The ecological significance of sulfur in the energy dynamics of salt marsh and coastal marine sed- iments. Biogeochem 1:5-27

Isaksen MF, Finster K (1996) Sulphate reduction in the root zone of the seagrass Zostera noltii on the intertidal flats of a coastal lagoon (Arachon, France). Mar Ecol Prog Ser 137: $187-194$

Jacobs RPWM (1979) Distribution and aspects of the production and biomass of eelgrass, Zostera marina L., at Roscoff, France. Aquat Bot 7:151-172

Jorgensen BB (1978) A comparison of methods for the quantification of bacterial sulfate reduction in coastal marine sediments: I. Measurement with radiotracer techniques Geomicrobiol J 1:11-27

Kemp WM, Boynton WR, Twilley RR, Stevenson JC, Ward LG (1984) Influences of submersed vascular plants on ecological processes in upper Chesapeake Bay. In: Kennedy VS (ed) The estuary as a filter. Academic Press, New York p $367-394$

Kenworthy WJ, Zieman JC, Thayer GW (1982) Evidence for the influence of seagrasses on the benthic nitrogen cycle in a coastal plain estuary near Beaufort, North Carolina (USA). Oecologia 54:152-158

Koepfler ET, Benner R, Montagna PA (1993) Variability of dissolved organic carbon in sediments of a seagrass bed and an unvegetated area within an estuary in Southern Texas. Estuaries 16(3A):391-404

Kraemer GP, Alberte RS (1995) Impact of daily photosynthetic priod on protein synthesis and carbohydrate stores in Zostera marina L. (eelgrass) roots: implicatıons for survival in light-limited environments. J Exp Mar Biol Ecol 185: $191-202$

Kristensen $E$, Andersen $F \varnothing$ (1987) Determination of organic carbon in marine sediments: a comparison of two CHNanalyzer methods. J Exp Mar Biol Ecol 109:15-23

Kristensen E, Hansen K (1995) Decay of plant detritus in organic-poor marme sediment: Production rates and stoichiometry of dissolved $\mathrm{C}$ and $\mathrm{N}$ compounds. J Mar Res 53 $675-702$

López NI, Duarte CM, Vallespinós F, Romero J, Alcoverro I (1995) Bacterial activity in NW Mediterranean seagrass (Posidonia oceanica) sediments. J Exp Mar Biol Ecol 187 . $39-49$

Moeslund L, Thamdrup B, Jørgensen BB (1994) Sulfur and iron cycling in a coastal sediment: radiotracer studies and seasonal dynamics. Biogeochem 27:129-152

Moriarty DJW, Boon PI, Hansen JA, Hunt WG, Poiner IR, Pollard PC, Skyring GW, White DC (1985) Microbial biomass and productivity in seagrass beds. J Geomicrob 4:21-51

Olesen B, Sand-Jensen K (1994) Biomass-density patterns in the temperate seagrass Zostera marina. Mar Ecol Prog Ser 109:283-291

Orth RJ, Moore KA (1983) Chesapeake Bay: an unprecedented decline in submerged aquatic vegetation. Science 222:51-52

Parkes RJ, Gibson GR, Mueller-Harvey I, Buckingham WJ Herbert RA (1989) Determination of the substrates for sulphate-reducing bacteria within marine and estuarıne sediments with different rates of sulphate reduction. J Gen Microbiol 135:175-187

Pérez-Lloréns JL, Niel FX (1993) Seasonal dynamics of biomass and nutrient content in the intertidal seagrass Zostera noltii Hornem. from Palmones River estuary, Spain. Aquat Bot 46:49-66

Robertson A., Mann KH (1984) Disturbance by ice and lifehistory adaptations of the seagrass Zostera marina. Mar Biol 80:131-141

Sand-Jensen K (1975) Biomass, net production and growth dynamics in an eelgrass (Zostera marina L.) population in 
Vellerup Vig, Denmark. Ophelia 14:185-201

Sand-Jensen K, Prahl C, Stockholm H (1982) Oxygen release from roots of submerged aquatic macrophytes. Oikos 38 $349-354$

Smith RD, Dennison WC, Alberte RS (1984) Role of seagrass photosynthesis in root aerobic processes. Plant Physiol 74 $1055-1058$

Smith RD, Pregnall AM, Alberte RS (1988) Effects of anaerobiosis on root metabolism of Zostera marina (eelgrass): implications for survival in reducing sediments. Mar Biol 98:131-141

Thamdrup B, Fossing $H$, Jørgensen BB (1994) Manganese, iron, and sulfur cycling in a coastal marine sediment

This article was submitted to the editor
(Aarhus Bay, Denmark). Geochim Cosmochim Acta 58 (23):5115-5129

Thode-Andersen S, Jorgensen BB (1989) Sulfate reduction and the formation of ${ }^{35} \mathrm{~S}$-labeled $\mathrm{FeS}, \mathrm{FeS}_{2}$ and $\mathrm{S}^{0}$ in coastal marine sediments. Limnol Oceanogr 34(5):793-806

Velimirov B (1987) Organic matter derived from a seagrass meadow: origin, properties and quality of particles. PSZN I: Mar Ecol 8:143-173

Wium-Andersen S, Borum J (1984) Biomass variation and autotrophic production of an epiphyte-macrophyte community in a coastal Danish area: I. Eelgrass (Zostera marina L.) biomass and net production. Ophelia 23(1): $33-46$

Manuscript first received: April 18, 1996

Revised version accepted: November 25, 1996 